\title{
Human Rights and the Challenges of Science and Technology
}

\section{Citation}

Marks, Stephen P. 2014. "Human Rights and the Challenges of Science and Technology." Science and Engineering Ethics (February 12).

\section{Published Version}

doi:10.1007/s11948-014-9518-z

\section{Permanent link}

http://nrs.harvard.edu/urn-3:HUL.InstRepos:12561403

\section{Terms of Use}

This article was downloaded from Harvard University's DASH repository, and is made available under the terms and conditions applicable to Open Access Policy Articles, as set forth at http:// nrs.harvard.edu/urn-3:HUL.InstRepos:dash.current.terms-of-use\#OAP

\section{Share Your Story}

The Harvard community has made this article openly available.

Please share how this access benefits you. Submit a story.

\section{Accessibility}


Human Rights and the Challenges of Science and Technology

Commentary on Meier et al. "Translating the Human Right to Water and Sanitation into Public Policy Reform" and Hall et al. "The Human Right to Water: The Importance of Domestic and Productive Water Rights"

To be published in Science and Engineering Ethics (Springer, 2014)

\author{
Author: Stephen P. Marks
}

\begin{abstract}
The expansion of the corpus of international human rights to include the right to water and sanitation has implications both for the process of recognizing human rights and for future developments in the relationships between technology, engineering and human rights. Concerns with threats to human rights resulting from developments in science and technology were expressed in the early days of the United Nations (UN), along with the recognition of the ambitious human right of everyone "to enjoy the benefits of scientific progress and its applications." This comment explores the hypothesis that the emerging concepts most likely to follow recognition of the human right to water primarily involve issues of science and technology, such as access to medicines or clean and healthy environment. Many threats to human rights from advances in science, which were identified in the past as potential, have become real today, such as invasion of privacy from electronic recording, deprivation of health and livelihood as a result of climate change, or control over individual autonomy through advances in genetics and neuroscience. This comment concludes by urging greater engagement of scientists and engineers, in partnership with human rights specialists, in translating normative pronouncements into defining policy and planning interventions.
\end{abstract}

Key words: Human rights, human right to science, misuse of science, UNESCO, International Bioethics Committee, Human Rights Council.

\title{
The right to water and the human rights norm-creating process
}

The recognition of water and sanitation as a human right illustrates two useful lessons for understanding the relationships between technology, engineering and human rights. The first is the process by which human rights proliferate, and the potential dilution of fundamental rights. The second lesson has to do with the ambiguity of human rights as either a constraint on, or an encouragement to science and its applications. Should human rights guide public policy to slow or stop research and development in certain areas? Or rather, is human rights a normative framework to promote advances in science and technology?

Meier et al. provide a narrative of how a claim (in this case to improved water and sanitation) was transformed into an internationally recognized human right through formal vote of the international community ("Translating the Human Right to Water and Sanitation into Public Policy Reform," 2014 ). Hall et al. propose a broadening of the definition of the right to water in order to "more effectively address a comprehensive range of socio-economic rights in rural and peri-urban areas" ("The Human Right to Water: The Importance od Domestic and 
Productive Water Rights" 2013). Both assume the value of expanding the corpus of international human rights. While Meier et al. are concerned about translating this right from formal international and national pronouncements into practical action at the local level, Hall et al. suggest "adopting a more holistic interpretation of existing international law on the human right to water" (Hall et al. 2013).

This process in the case of the right to water was novel in that the main human rights instruments do not refer to access to potable water for drinking and adequate systems of sanitation as a human right, except as an implied element of the right to an adequate standard of living, including food and health. This was the case until the adoption by the United Nations (UN) Committee on Economic, Social and Cultural Rights in 2002 of the General Comment on the Right to Water (CG15) (United Nations 2002) and, eight years later, the adoption by the General Assembly of Resolution 64/292 (United Nations 2010). The Committee drew on three main arguments to construct this right: one based on evidence, one on logic, and the third on legal construction. The Committee cited evidence from the World Health Organization of the magnitude of the uncontested and urgent problem of water: "Over one billion persons lack access to a basic water supply, while several billion do not have access to adequate sanitation, which is the primary cause of water contamination and diseases linked to water" (United Nations 2002). The second argument is based on a logical construction, according to which water as a human right is a necessary consequence of the nature of this commodity: "Water is a limited natural resource and a public good fundamental for life and health. The human right to water is indispensable for leading a life in human dignity. It is a prerequisite for the realization of other human rights" (United Nations 2002). The third basis for positing the right to water as a human right is the legal interpretation of existing human rights norms: "The right to water has been recognized in a wide range of international documents, including treaties, declarations and other standards" (United Nations 2002). Thus the right to water and sanitation bypassed most of the steps in the norm-creating process.

A derivative right, it is difficult to claim the right to water is a binding norm. Indeed, states have committed to what is written in the treaties but are not legally bound by how expert bodies interpret them. The concept of derivative rights can be valuable in strengthening the legal architecture of human rights, not to contribute to the proliferation of rights but rather to identify the evolving practice that can crystallize into what is called a lex ferenda, that is, a norm that is evolving in the direction of becoming recognized law. It has long been argued that new rights must be subjected to "quality control" to avoid expanding the list of rights unproductively (Alston 1984). The most likely candidate-rights to follow the path of the right to water and sanitation in this emerging trend to expand on the list of human rights - such as the right to essential medicines and devices, the right to a safe, clean, healthy and sustainable environment, or the right to tobacco control as derivative from the right to health and to life- have close links to advances in science and technology (Dresler, C. \& Marks, S. 2006; Marks 2009). It may be useful, therefore, to recall the way in which the relation between human rights and science and technology has been dealt with in the past.

\section{The right to benefit from advances in science and technology}

In its 1947 statement on the "Grounds of an International Declaration of Human Rights," the Committee on the Theoretical Bases of Human Rights, convened by UNESCO, included a 
"Right to Share in Progress" according to which "every man has the right to fully access the enjoyment of the technical and cultural achievements of civilization" (UNESCO 1948). According to committee member J. M. Burgers, Professor at the Technical College of Delft, the Netherlands, "the part played by science in modern society makes possible and at the same time puts upon us the obligation of international co-operation, as well as of looking into the future in the interest of coming generations" (UNESCO 1948). He articulated a duty of the community "of setting aside from its funds means for elaborate scientific research, as a means for alleviating wants of mankind, for the development of mankind, and for the pursuit of truth" (UNESCO 1948).

These ideas are reflected in article 27 of the Universal Declaration of Human Rights, followed by the International Covenant on Economic, Social and Cultural Rights (ICESCR), which stipulates in Article 15 that States Parties "recognize the right of everyone" both "to enjoy the benefits of scientific progress and its applications" and "to benefit from the protection of the moral and material interests resulting from any scientific, literary or artistic production of which he is the author" (United Nations 1966). This right was indirectly alluded to in the 1975 Declaration on the Use of Scientific and Technological Progress in the Interest of Peace and for the Benefit of Mankind (United Nations 1975). In that declaration, the General Assembly called for "measures to extend the benefits of science and technology to all strata of the population..." (United Nations 1975). UNESCO's Intergovernmental Bioethics Committee (IGBC) and the International Bioethics Committee (IBC) addressed access to science and technology in the 1997 Universal Declaration on the Human Genome and Human Rights ("states should seek to encourage measures enabling ... developing countries to benefit from the achievements of scientific and technological research so that their use in favour of economic and social progress can be to the benefit of all") (UNESCO 1997), and the 2005 Universal Declaration on Bioethics and Human Rights ("The aims of this Declaration are ... (d) to recognize the importance of freedom of scientific research and the benefits derived from scientific and technological developments... [and] to promote equitable access to medical, scientific and technological developments as well as the greatest possible flow and the rapid sharing of knowledge concerning those developments and the sharing of benefits, with particular attention to the needs of developing countries") (UNESCO 2005).

Even more explicit is Article 15 of the Universal Declaration on Bioethics and Human Rights on sharing of benefits, in which the General Conference of UNESCO affirms that "Benefits resulting from any scientific research and its applications should be shared with society as a whole and within the international community, in particular with developing countries" and enumerates seven forms of cooperation to give effect to this principle: "(a) special and sustainable assistance to, and acknowledgement of, the persons and groups that have taken part in the research; (b) access to quality health care; (c) provision of new diagnostic and therapeutic modalities or products stemming from research; (d) support for health services; (e) access to scientific and technological knowledge; (f) capacity-building facilities for research purposes; ( $g$ ) other forms of benefit consistent with the principles set out in this Declaration" (UNESCO 2005).

The right to enjoy the benefits of scientific progress was recently resuscitated in part by UNESCO (UNESCO 2009) and in part through a project of the American Association for the Advancement of Science (AAAS), which led, among other outcomes, to a Board of Directors' Statement recognizing the right as lying at the heart of the mission of the organization (AAAS 
2010), an article in Science magazine (Chapman, A., \& Wyndham, J., 2013) and a study on United States (US)-based scientists' perspectives on the meaning and application of the right (AAAS 2013).

\section{Threats to human rights from science and technology}

The dangers of the misuse of science were also a concern of the UN in the 1940s through the 1990s anticipating several issues that occupy the front pages today. The International Conference on Human Rights of 1968 adopted the Proclamation of Tehran predicting that, "[w]hile recent scientific discoveries and technological advances have opened vast prospects for economic, social and cultural progress, such developments may nevertheless endanger the rights and freedoms of individuals and will require continuing attention" (United Nations 1968a). In a follow-up resolution, the General Assembly agreed that "recent scientific discoveries and technological advances ... may ... endanger the rights and freedoms of individuals" and requested a study on four issues of concern with regard to human rights arising out of science and technological advancement, namely, (1) respect for privacy "in light of advances in recording and other techniques;" (2) protection of physical and intellectual integrity in light of advances in biology, medicine and biochemistry; (3) limits on the use of electronics to protect the rights of individuals; and (4) "generally, the balance that should be established between scientific and technological progress and the intellectual, spiritual, cultural and moral advancement of humanity" (United Nations 1968b). The final report was issued at the end of December 1970, covering all the issues assigned, as well as the hazards arising from atomic radiation (United Nations 1970; Weeramantry, C. G. 1990).

Five years later, the Declaration on the Use of Scientific and Technological Progress in the Interest of Peace and for the Benefit of Mankind was adopted, expressing concern "that scientific and technological achievements can be used to ... deprive individuals and peoples of their human rights and fundamental freedoms" and calling on states to "take appropriate measures to prevent the use of scientific and technological developments, particularly by the State organs, to limit or interfere with the enjoyment of the human rights and fundamental freedoms of the individual." (United Nations 1975)

Almost two decades later, the World Conference on Human Rights (1993) adopted the Vienna Declaration and Program of Action, which noted "that certain advances, notably in the biomedical and life sciences as well as in information technology, may have potentially adverse consequences for the integrity, dignity and human rights of the individual, and call[ed] for international cooperation to ensure that human rights and dignity are fully respected in this area of universal concern." (United Nations 1993)

These early concerns of the United Nations regarding the negative impact that certain aspects of science and technology can have on human rights anticipate many urgent issues we face today.

\section{Conclusion}

The concerns expressed in the 1968 and 1993 World Conferences on Human Rights cited above are hauntingly reflected in recent developments, such as the revelations on use of recording and other technologies by the US National Security Agency (NSA). The General 
Assembly called for a study in 1968 on "respect for the privacy of individuals and the integrity and sovereignty of nations in light of the advances in recording and other techniques" (United Nations, 1968b). The Electronic Frontier Foundation (EFF) commented 45 years later, "[n]ew technologies are ... enabling unparalleled invasions of privacy," adding that "[n]ational and international laws have yet to catch up with the evolving need for privacy that comes with new technology" (EFF 2013). Recalling the concern expressed by two UN Special Rapporteurs on the promotion and protection of human rights and fundamental freedoms while countering terrorism, the UN High Commission for Human Rights recently mentioned "national security surveillance, which, increasingly, impacts on the right to privacy of individuals." (Pillay 2013).

The World Conferences also expressed concern regarding scientific progress in genomics, robotics, neuroscience, reproductive health technology and other fields of biomedicine and the life sciences. In 1971, George Brand, a UN official writing in an academic journal, anticipated many of the developments we are witnessing today. Referring to "artificial inovulation; in vitro fertilization; partheno-genesis; choice of sex of offspring; creation of human beings by an asexual process called cloning; manipulation of the DNA molecule so as to interfere with the processes of heredity ('genetic surgery'); the improvement, by procedures adopted before birth, of the future intelligence of a child; and the creation of part-human chimeras," he warned that "It is easy but dangerous, to dismiss all of these possibilities as science fiction" (Brand, 1971). The advances in the relevant scientific fields raise complex challenges for human rights today, which can only be addressed with the cooperation of medical specialists, geneticists, cell biologists, neuroscientists and others in the scientific community in dialogue with human rights experts.

Technologies that pollute and contribute to climate change are harmful to the rights to health and to water, among others, while technologies that mitigate harmful emissions and allow people to adapt in ways that protect them from harm contribute to the realization of these rights. In its latest of several resolutions on human rights and climate change, the Human Rights Council emphasized "that climate change-related impacts have a range of implications, both direct and indirect, for the effective enjoyment of human rights, including, inter alia, the right to life, the right to adequate food, the right to the highest attainable standard of health, the right to adequate housing, the right to self-determination and the right to safe drinking water and sanitation, and recalling that in no case may a people be deprived of its own means of subsistence" (United Nations 2011).

If there is a continuing trend, exemplified by the right to water as presented by Meier, et al. (2014 ) and Hall et al. (2013), to develop new or derivative human rights in a wide range of scientific and technological fields, the engagement of scientists and engineers, in partnership with human rights specialists, will be essential to translate normative pronouncements into "enhanced opportunities for rights-based ... policy" and "actual interventions" (Hall et al., 2013). This special section of Science and Engineering Ethics on technology, engineering and human rights is a good beginning.

Acknowledgement: The author wishes to thank Jessica Wyndham and Natalie Gyenes for their assistance and suggestions in developing this manuscript. 


\section{References:}

American Association for the Advancement of Science (AAAS) (2010). Advancing Science Serving Society Statement: On the human right to the benefits of scientific progress. Retrieved November 1, 2013, from http://shr.aaas.org/article15/Reference_Materials/Article15_AAASBoardStatement.pdf

AAAS Science and Human Rights Coalition, "Defining the Right to Enjoy the Benefits of Scientific Progress and Its Applications: American Scientists' Perspectives" (Report prepared by Margaret Weigers Vitullo and Jessica Wyndham), October 2013.DOI: 10.1126/srhrl.aaa0028. Retrieved November 5, 2013 from http://srhrl.aaas.org/coalition/WG/3/Projects/Article15/UNReportAAAS.pdf

Alston, P. (1984). Conjuring up new human rights: a proposal for quality control. American Journal of International Law, 78(3), 607-621.

Brand, G. (1971). Human rights and scientific and technological developments. Human Rights Journal, 4, 354.

Burgers, J. M. (1948). Rights and duties concerning creative expression in particular in science. In UNESCO (1948). Human rights: comments and interpretations, p. 216.

Chapman, A. \& Wyndham, J. (2013). A human right to science. Science, 340(6138), 1291, doi: 10.1126/science. 1233319

Dresler, C. \& Marks, S. (2006). The emerging human right to tobacco control. Human Rights Quarterly, 28(3), 559-651.

Electronic Frontier Foundation (EFF).(2013). Privacy. Retrieved November 1, 2013, from https://www.eff.org/issues/privacy

Hall, R.P., Van Koppen, B. \& Van Howeling, E. (2013) The Human Right to Water: The Importance of Domestic and Productive Water Rights, Science and Engineering Ethics, this issue, doi: 10.1007/s11948-013-9499-3.

Marks, S. (2009). Access to essential medicines as a component of the right to health. In A. Clapham \& M. Robinson (Eds.), Realizing the Right to Health. Zurich, Switzerland: Rüfer \& Rub, the Swiss Human Rights Book Series. Pp. 82-101.

Meier, B.M., Kestenbaum, J.G., Kayser, G.L., Amjad, U.Q., Dalcanale, F. \& Bartram, J. (2014) Translating the Human Right to Water and Sanitation into Public Policy Reform. Science and Engineering Ethics, this issue. doi:10.1007/s11948-013-9504-x.

United Nations (1948). The Universal Declaration of Human Rights. New York: United Nations. Retrieved November 1, 2013, from http://www.un.org/en/documents/udhr/index.shtml

United Nations (1966). International Covenant on Economic, Social and Cultural Rights. art. 15(1)(c). Retrieved November 1, 2013, from http://www2.ohchr.org/english/law/cescr.htm 
United Nations (1968a), Proclamation of Teheran, Final Act of the International Conference on Human Rights, Teheran, 22 April to 13 May 1968, U.N. Doc. A/CONF. $32 / 41$ (1968). Para. 18. Retrieved November 3, 2013 from http://legal.un.org/avl/pdf/ha/fatchr/Final_Act_of_TehranConf.pdf

United Nations (1968b). Resolution adopted by the General Assembly. 2450 (XXIII). U.N. Doc. A/10034. Para. 1(a).

United Nations (1970), Human rights and scientific and technological developments. U.N. Doc. E/CN.4/1028/Add.6 (Dec. 29, 1970), and A/8055.

United Nations (1975). Declaration on the Use of Scientific and Technological Progress in the Interest of Peace and for the Benefit of Mankind. General Assembly. Resolution 3384 (XXX).

United Nations (1993) Vienna Declaration and Program of Action, ๆ 11, U.N. Doc. A/CONF.157/23 (July 12, 1993).

United Nations (2002). Committee on Economic, Social and Cultural Rights. The Right to Water (arts. 11 and 12 of the International Covenant on Economic, Social and Cultural Rights), General Comment No. 15. U.N. Doc. E/C.12/2002/11 (2002).

United Nations (2011). Human Rights Council resolution 18/22, adopted on 30 September 2011.

United Nations (2013). Opening Remarks by Ms. Navi Pillay, United Nations High Commissioner for Human Rights to the Side-event at the 24th session of the UN Human Rights Council How to safeguard the right to privacy in the digital age? 20 September 2013, 12:00 to 14:00 Room XXI, Palais des Nations, Geneva. Retrieved November 3, 2013 from http://www.ohchr.org/en/NewsEvents/Pages/NewsSearch.aspx?PTID=HC\&NTID=STM

United Nations Educational, Scientific and Cultural Organization (UNESCO). (1948). Human rights: comments and interpretations. Grounds of an International Declaration of Human Rights, Appendix II, p. 14.

UNESCO (1997). Universal declaration on the human genome and human rights. art. 19(a)(iii), UNESCO 29 C/Res. 31 (Nov. 11, 1997).

UNESCO (2005). Universal declaration on bioethics and human rights. arts. 2(d), (f), UNESCO. SHS/EST/BIO/06/1 (Oct. 19, 2005).

UNESCO (2009). The Right to Enjoy the Benefits of Scientific Progress and its Applications. Paris: UNESCO, 2009.

Weeramantry, C. G. (1990). Human Rights and Scientific and Technological Development: Studies on the Affirmative Use of Science and Technology for the Furtherance of Human Rights. United Nations University Press, 1990. 